Review

\title{
Development of Recombinant Immunotoxins for Hairy Cell Leukemia
}

\author{
Robert J. Kreitman ${ }^{1,2, *}$ and Ira Pastan 1 (1) \\ 1 Laboratory of Molecular Biology, Clinical Center, National Cancer Institute, National Institutes of Health, \\ Bethesda, MD 20892, USA; pastani@mail.nih.gov \\ 2 National Institutes of Health, Building 37/5124b, 9000 Rockville Pike, Bethesda, MD 20892, USA \\ * Correspondence: kreitmar@mail.nih.gov; Tel.: +1-301-648-7375
}

Received: 20 June 2020; Accepted: 24 July 2020; Published: 3 August 2020

\begin{abstract}
Hairy cell leukemia (HCL) is an indolent B-cell malignancy with excellent initial response to purine analogs pentostatin or cladribine, but patients are rarely, if ever, cured. Younger patients will usually need repeat chemotherapy which has declining benefits and increasing toxicities with each course. Targeted therapies directed to the BRAF V600E mutation and Bruton's tyrosine kinase may be helpful, but rarely eradicate the minimal residual disease (MRD) which will eventually lead to relapse. Moxetumomab pasudotox (Moxe) is an anti-CD22 recombinant immunotoxin, which binds to CD22 on HCL cells and leads to apoptotic cell death after internalization and trafficking of the toxin to the cytosol. Phase I testing achieved a complete remission (CR) rate of $57 \%$ in relapsed/refractory HCL. Most CRs were without MRD and eradication of MRD correlated with prolonged CR duration. Patients were often MRD-free after five years. Important mild-moderate toxicities included capillary leak and hemolytic uremic syndromes which could be prevented and managed conservatively. A phase 3 trial met its endpoint of durable $\mathrm{CR}$ with acceptable toxicity, leading to FDA approval of Moxe for relapsed/refractory HCL, under the name Lumoxiti. Moxe combined with rituximab is currently being evaluated in relapsed/refractory HCL to improve the rate of MRD-free CR.
\end{abstract}

Keywords: hairy cell leukemia; treatment; rituximab; moxetumomab pasudotox; minimal residual disease

\section{Introduction to Hairy Cell Leukemia}

Hairy cell leukemia (HCL) is a B-cell malignancy comprising $2 \%$ of leukemias [1,2], amounting to about 1200 new cases per year in the United States [3]. Over 90\% of classic HCL cases have the BRAF V600E mutation, which leads to constitutive phosphorylation of ERK and increased proliferation [4-7]. Other mutations have been reported in classic HCL, in association with BRAF V600E [8-10]. Patients often report a history of occupational or residential exposure to chemicals [11-14], but there is no association with tobacco smoking [15]. Although indolent, the median survival after diagnosis was only four years in 1978 prior to the advent of effective therapies [16]. First-line treatment of HCL underwent a major advance in the late 1980s with the use of purine analogs pentostatin or cladribine, each capable of achieving complete remission (CR) in $76-91 \%$ of patients [17-23]. Extended follow-up showed high 5- and 10-year disease-free survival rates, but without a plateau on the disease-free survival curves, indicating a lack of evidence of cure [24,25]. Although first-line treatment of HCL remains single-agent purine analog [26,27], repeat use is associated with declining CR rates, shorter disease-free intervals, and increasing risk of toxicity with each course, particularly from chronic T-lymphopenia and neuropathy [28-31]. Repeated treatments are also associated with an increased risk of secondary malignancies [32]. Outcomes using single-agent purine analogs are much poorer with variants of HCL [33-35], highlighting the importance of a correct initial diagnosis. 


\section{Diagnosis of HCL}

HCL patients present most commonly with fatigue $(80 \%)$, and also with poor appetite, fever, weight loss, infections, night sweats, left upper abdominal pain from splenomegaly, and bruising from thrombocytopenia [36]. Patients classically have monocytopenia although sometimes the HCL cells are mistaken for monocytes based on their size [37]. The diagnosis can most specifically and sensitively be made by blood or bone marrow aspirate flow cytometry, which should show bright positivity for CD22, CD20, and CD11c. CD103 is expressed on normal T-cells but is a specific marker for HCL if found on B-cells [36,38]. In classic HCL, CD25 is positive but may be dim to bright, and CD123 is usually positive as well. By bone marrow biopsy immunohistochemistry (IHC), the most common markers include CD20, CD22, and CD19, which also stain normal B-cells, and the more HCL-specific markers tartrate-resistant acid phosphatase (TRAP), DBA44 (CD72), annexin 1A (Anxa1), and the BRAF V600E mutation using the VE1 antibody [4,36,39]. Double staining for Pax5 and either TRAP or CD103 can be highly specific for HCL [40]. The BRAF V600E mutation can also be detected by several PCR techniques including pyrosequencing [7], or allele-specific quantitative PCR [5]. A popular method is digital droplet PCR [41]. Although cytopenias can be observed for years prior to the diagnosis, patients present at a median age of about 55 . Three to four times as many patients are male vs. female and HCL is observed more commonly in Caucasians compared with Asians, Arabs, and Africans [15]. DRB1*11, a class II human leukocyte antigen (HLA), is expressed more commonly in HCL compared with the control Caucasian populations, and DRB1*11 is more frequent in Caucasians than in other populations [42].

\section{Differentiation of HCL from Variants}

In 1980, Cawley et al. described a variant of HCL where patients had more frequent leukocytosis with less cytopenias including less monocytopenia [43,44]. Now called HCLv, this variant lacks CD25, TRAP, Anxa1, and BRAF V600E, is more aggressive than HCL, and in 2008 was considered a distinct disorder by the World Health Organization $[7,43,44]$. HCLv differs from HCL in its intra-sinusoidal morphology in bone marrow $[35,39,44]$. Response of HCLv to single-agent purine analog is poor and requires combinations of purine analog and rituximab [34,45]. Thus, an accurate diagnosis of HCL vs. HCLv is critical. By flow cytometry, CD11c is as bright in HCLv as in classic HCL, but CD25 and usually CD123 are negative [38,44]. CD103 is positive in both HCL and HCLv and its absence requires consideration of splenic marginal zone lymphoma (SMZL) [38,46]. SMZL can be differentiated from HCL and HCLv since SMZL is mainly a white pulp disease $[39,44]$, while HCL/HCLv involve the red pulp of the spleen. Both splenic diffuse red pulp lymphoma (SDRPL), and HCLv are considered "splenic B-cell lymphoma/leukemia, unclassifiable" [35], although SDRPL has less lymphocytosis, anemia, longer overall survival from diagnosis, brighter CD123, and lower CD11c and CD103 expression [35]. A subset of HCLv expresses unmutated immunoglobulin rearrangement IGHV4-34 [33]. IGHV4-34+ HCL can also have an immunophenotype like classic HCL (TRAP+, bright CD25+) but remains aggressive, lacks BRAF V600E, is associated with nodal disease, and responds poorly to first-line purine analog. Thus, IGHV4-34+ HCL/HCLv may be considered a molecularly defined variant overlapping with HCLv $[7,33,47,48]$. Aberrant markers in classic HCL like CD38 may be associated with shorter time to salvage therapy [49], but other non-HCL markers like CD5 or CD10 may be expressed without prognostic implications [50-53].

\section{When Treatment Is Indicated in HCL}

Although some patients may not need treatment for years or decades, most do and the most common indications for treatment include neutrophils $<1-1.5 \times 10^{9}$ cells/L, hemoglobin $<10-12$ $\mathrm{g} / \mathrm{dL}$, and platelets $<100 \times 10^{9}$ cells/L $[19,21,27,54]$. We and others favor the more stringent $<1,<10$, and $<100$ limits of these respective criteria given the toxicity of chemotherapy for HCL and the importance of avoiding excessive retreatment [21,55-60]. Additional criteria for treatment include 
malignant lymphocytosis $>5$ or $>20 \times 10^{9} / \mathrm{L}$, symptomatic splenomegaly, enlarging lymph nodes $>2 \mathrm{~cm}$, and frequent infections. Additional criteria are particularly important for those without cytopenias, like in HCLv or in HCL after splenectomy, since these patients would otherwise not qualify for clinical trials until much more advanced. After prior therapy, it is important to determine whether cytopenias are treatment- or disease-related. An important pitfall to avoid is to perform a bone marrow too early after treatment, and if residual disease is visible administer more therapy. Such a patient might achieve $\mathrm{CR}$ without further treatment. For this reason, post-treatment bone marrow biopsies should be delayed at least four-six months after last treatment [27]. Even so, it may still be difficult to determine whether the presence of residual disease and cytopenias indicate the need for additional treatment. In this situation, it is often helpful to obtain peripheral blood flow cytometry at several points in time: an increasing HCL count indicates the cytopenias are due to the residual disease, while undetectable HCL cells in the blood often indicate a good response to last treatment and suggest cytopenias might resolve with additional time.

\section{Criteria for Response in HCL}

By the 1987 Consensus Resolution [61], and the more recent 2017 guidelines [26,27], CR requires elimination of HCL cells by morphologic (non-immunologic) stains, like Wright stain of blood and bone marrow aspirate, and hematoxylin/eosin (H/E) stain of the bone marrow biopsy. Resolution of cytopenias is required for neutrophils $\geq 1.5 \times 10^{9} / \mathrm{L}$, hemoglobin $\geq 11-12 \mathrm{~g} / \mathrm{dL}$, and platelets $\geq 100 \times$ $10^{9} / \mathrm{L}[27,55-62]$. We typically drop the hemoglobin requirement when iron deficiency is documented, since patients often have limited iron stores pretreatment and iron deficiency may limit rapid recovery of normal red blood cells. Table 1 lists the consensus response criteria along with variations or additions used. Partial response (PR) requires at least a 50\% reduction in palpable spleen, liver, and lymph node size, and resolution of cytopenias to levels required by CR. We and others accept at least 50\% improvement in neutrophils, hemoglobin, and platelets as sufficient for PR [21,55-60,62,63]: a PR with resolution of cytopenias to CR levels has been considered a "good PR" (GPR) [62] or a hematologic remission (HR) $[59,60,64,65]$. We consider a patient receiving blood transfusions at baseline to have achieved a PR if hemoglobin improved to $\geq 9.0 \mathrm{~g} / \mathrm{dL}$ even if the baseline was $>6.0 \mathrm{~g} / \mathrm{dL}$, provided the improvement occurred $\geq 4$ weeks after last blood transfusion or growth factor [60]. Similarly, resolution of neutropenia should occur $\geq 4$ weeks after last growth factor. A minimum duration of resolved cytopenias was not specified in the guidelines [27], but four weeks is often used $[19,59,60,62,64-66]$. We require four weeks for multiple relapsed HCL protocols, but a single assessment for first- or second line HCL treatment, since improvements are more durable after therapy of early HCL [66,67]. The older PR criteria requiring $\leq 5 \%$ circulating HCL is no longer required for PR [27], although many protocols including ours required $\geq 50 \%$ reduction in peripheral blood HCL cell count $[19,21,68]$. The PR requirement for $\geq 50 \%$ reduction in HCL infiltration by bone marrow biopsy [61] is one that we avoid due to the heterogenicity and hence inaccuracy of bone marrow biopsy in quantifying marrow infiltration. We also try to limit posttreatment bone marrow procedures to those patients who might qualify for CR, rather than perform them in patients just to document PR. To avoid investigator bias in clinical trials, imaging with CT or MRI is often used instead of physical exam or ultrasound for documenting resolution in adenopathy and splenomegaly. If so, resolution of lymph nodes to $\leq 2 \mathrm{~cm}$ in short axis, and resolution of spleens to either $\leq 17 \mathrm{~cm}$ in diameter or $>25 \%$ decreased from baseline can be considered consistent with CR. A $\geq 50 \%$ reduction in products of lymph node perpendicular diameters or reduction to a size consistent with CR by CT or MRI is considered consistent with PR. It is notable that residual splenomegaly and hypersplenism causing thrombocytopenia may remain in the absence of residual disease, and splenectomy may not be indicated in these cases [69]. Blood flow cytometry and serum soluble CD25 or CD22 [70] may be helpful in ruling out residual splenic involvement. Residual adenopathy $>2 \mathrm{~cm}$ in short axis can often indicate residual HCL in patients otherwise appearing disease-free, and such patients may require lymph node biopsy to determine response. 
Table 1. Criteria for response in hairy cell leukemia (HCL).

\begin{tabular}{|c|c|c|}
\hline & Consensus Guidelines [26,27] & Variations \\
\hline \multicolumn{3}{|c|}{ Complete remission (CR) } \\
\hline $\mathrm{CBC}$ & ANC $>1.5, \mathrm{Hgb}>11$, and Plt 100 & $\mathrm{Hgb} \geq 12$ for males [62] \\
\hline CBC duration & One resolved $\mathrm{CBC}$ is sufficient & $\begin{array}{c}\text { Resolved CBCs } \geq 4 \text { weeks } \\
{[19,59,60,62,64-66]}\end{array}$ \\
\hline HCL cells & $\begin{array}{l}\text { Absent in blood and marrow by } \\
\text { morphology }\end{array}$ & \\
\hline Spleen & Absent on exam & Resolved by CT/MRI [65] \\
\hline Lymph nodes & Not specified & $\begin{array}{c}\text { Resolved to } \leq 2 \mathrm{~cm} \text { in short axis by } \\
\text { imaging/exam [66] }\end{array}$ \\
\hline \multicolumn{3}{|l|}{ CR, MRD-free } \\
\hline Bone marrow & $\begin{array}{l}\text { IHC Negative by CD20, DBA.44, } \\
\text { or VE1 }\end{array}$ & IHC and flow cytometry negative \\
\hline \multicolumn{3}{|l|}{ Partial response (PR) } \\
\hline CBC & Same as CR & $\begin{array}{l}\geq 50 \% \text { improvement in ANC, Hgb, } \\
\text { and Plt }[21,55-60,62,63]\end{array}$ \\
\hline CBC duration & No minimum duration & $\begin{array}{c}\text { Resolved CBC } \geq 4 \text { weeks } \\
{[19,59,60,62,64-66]}\end{array}$ \\
\hline Blood HCL & Not specified & $\geq 50 \%$ reduction $[19,21,68]$ \\
\hline Marrow HCL & $\geq 50 \%$ reduction in infiltration & Avoid due to heterogeneity $[64,65]$ \\
\hline Organomegaly & $\geq 50 \%$ reduction & $\begin{array}{l}\text { Require CT/MRI imaging due to } \\
\text { bias [65] }\end{array}$ \\
\hline \multicolumn{3}{|c|}{ Progressive disease (PD) } \\
\hline CBC & $\begin{array}{c}\geq 25 \% \text { decline in } \mathrm{ANC}, \mathrm{Hgb} \text {, or Plt, } \\
\text { due to } \mathrm{HCL}\end{array}$ & \\
\hline Symptoms & $\begin{array}{l}\text { Increase in symptoms related to } \\
\text { disease }\end{array}$ & \\
\hline Organomegaly & $\geq 25 \%$ increase in organomegaly & \\
\hline Lymph nodes & Not specified & $\begin{array}{c}\text { New lymph nodes or } \geq 25 \% \\
\text { increase in existing nodes }[65,71]\end{array}$ \\
\hline Blood HCL & Not specified & $\begin{array}{l}\geq 50 \% \text { increase in HCL cells or } \\
\text { absolute lymphocytes }[65,71]\end{array}$ \\
\hline$\underline{\text { Stable disease }}$ & Neither CR, PR, nor PD & \\
\hline
\end{tabular}

\section{Minimal Residual Disease (MRD)}

Since HCL has been studied for over 60 years, it is important to keep the definition for CR relatively constant, which is why $\mathrm{CR}$ criteria are limited to morphologic stains. With the advent of immunologic stains, HCL cells not apparent by H/E can readily be seen by immunohistochemistry. Blood and bone marrow flow cytometry using cocktails of antibodies can detect $<0.01 \%$ HCL cells. MRD criteria by immunohistochemistry include CD20+ or DBA44+ cells mostly consistent with HCL by morphology, and B-cells at least as numerous as T-cells [72]. We have used this older definition of immunohistochemistry MRD [67] since it is most established, but it lacks sensitivity compared with newer techniques like Pax5/CD103 or Pax5/TRAP double staining [40]. One might consider the presence of rare Pax5/CD103 or Pax5/TRAP double-stained cells (6-10 cells on the slide of a 1-2 cm core) to be positive for immunohistochemistry MRD. Additional correlation between immunohistochemistry 
and flow cytometry is currently being obtained using these double stains. Bone marrow aspirate flow cytometry is most sensitive by far for MRD $[34,64,66,67]$. A cutoff of $\geq 0.01 \%$ has been used in some studies [64,65], but in others, even suspicious MRD by flow cytometry has been considered positive [73]. Detecting resolution of MRD is particularly relevant for CR achieved by treatments capable of eradicating MRD, and this is a special feature of anti-CD22 recombinant immunotoxin.

\section{Introduction to Recombinant Immunotoxins}

Recombinant immunotoxins are engineered molecules containing a protein toxin genetically fused to a fragment of a monoclonal antibody [74]. They are like antibody drug conjugates (ADCs), in that they bind to the cell surface and kill the cell after internalization. However, in ADCs, the toxic moiety is a chemotherapeutic agent, which the cancer may be resistant to. In recombinant immunotoxins, the therapeutic payload is a protein toxin which kills by a different mechanism: catalytic inactivation of protein synthesis [75-78]. Protein synthesis arrest leads to a fall in MCL-1, and activation of BAK and the apoptotic cascade [79].

\section{Plant vs. Bacterial Toxins}

Plant toxins like ricin have been used to make chemical conjugates, including one targeting CD22 [80,81]. However, bacterial toxins like Pseudomonas exotoxin A (PE) and diphtheria toxin (DT) are more convenient for creating chimeric recombinant toxins, since these bacterial toxins are naturally made as single chains [82,83]. Unlike DT, humans do not get vaccinated against PE, which is derived from Pseudomonas aeruginosa, and only a minority of patients will have pre-existing antibodies capable of neutralizing PE. Immunotoxins are thought to work by binding to the host cell, internalizing and unfolding in an acidic endocytic vesicle [84], undergoing furin proteolytic cleavage between the ligand and toxin [85-87], reducing the disulfide bond holding the cleavage fragments together [88], trafficking of the released ADP-ribosylating fragment to the endoplasmic reticulum [89,90], translocation to the cytosol [91,92], and ADP-ribosylation of EF2 [93,94] causing protein synthesis inhibition and apoptotic cell death [79,95-98].

\section{LMB-2 Targeting CD25}

Figure 1 shows three recombinant immunotoxins tested in patients with hematologic malignancies. The first recombinant immunotoxin produced contains the variable domains of an anti-CD25 monoclonal antibody (Mab) anti-Tac arranged in single-chain $\mathrm{Fv}$ form, connected to a $40 \mathrm{kDa}$ truncated form of PE called PE40 [99,100]. Since PE40 is missing the binding domain 1a of PE, anti-Tac(Fv)-PE40 binds to CD25 rather than to normal cells. 

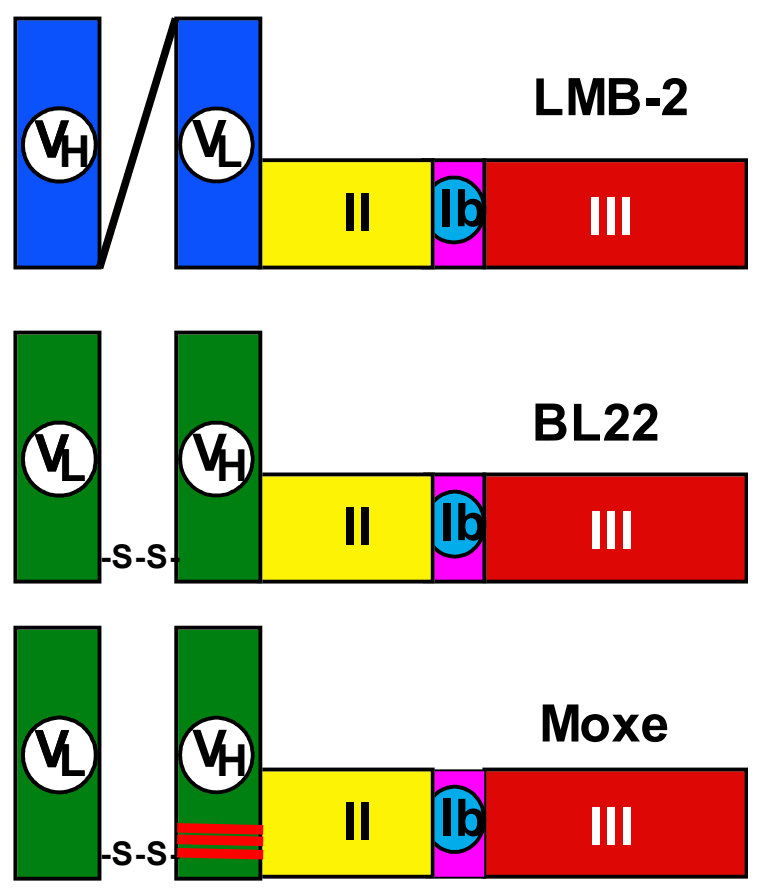

Figure 1. Recombinant immunotoxins targeting hematologic malignancies. LMB-2 development began in 1989 and led to the anti-CD25 single-chain recombinant immunotoxin LMB-2, also called anti-Tac(Fv)-PE38 [99-101]. The variable domains of the anti-CD25 Mab anti-Tac are connected by a peptide linker (GGGGS) 3 , and a shorter peptide connects $V_{L}$ with the $38 \mathrm{kDa}$ truncated form of PE called PE38. LMB-2 entered clinical testing in July 1996. BL22 contains the variable domains of the RFB4 Mab [102] targeting CD22. $\mathrm{V}_{\mathrm{H}}$ and $\mathrm{V}_{\mathrm{L}}$ are disulfide-stabilized by converting Arg44 of $\mathrm{V}_{\mathrm{H}}$ and Gly100 of $\mathrm{V}_{\mathrm{L}}$ to cysteines and allowing the disulfide bond to form during redox renaturation refolding [103]. The carboxy terminus of VH is connected to PE38. BL22 began clinical testing in February 1999. Moxetumomab pasudotox (Moxe) is an affinity-matured form of BL22 containing 3 mutations in $\mathrm{VH}$. Moxe began clinical testing in May 2007 and was approved by FDA in September 2018.

To improve protein folding during production, the connector between the variable domains and toxin was modified. PE40 was shortened to PE38 by removal of amino acids containing a disulfide bond, resulting in anti-Tac(Fv)-PE38 [104] or LMB-2. The anti-CD25 recombinant immunotoxin was cytotoxic toward primary leukemic cells from patients with CD25+ malignancies, including adult T-cell leukemia [101,105] and HCL [106]. In phase 1 testing in both T- and B-cell malignancies, the best results were observed in patients with HCL, with three PRs and one CR out of four patients $[55,56]$. Its success was based on the high expression of CD25 in most patients with classic HCL [106].

\section{Development of anti-CD22 Recombinant Immunotoxins for HCL}

CD22, also called Siglec 2, is expressed mainly by B-lymphocytes and functions to inhibit B-cell receptor signaling $[107,108]$. The rationale for the development of a CD22 recombinant immunotoxin was based on characteristics of both HCL and non-HCL hematologic malignancies. CD22 is expressed at a much higher level than CD25 in most classic HCL patients $[38,106]$. HCLv lacks CD25 expression but has high CD22 expression like classic HCL [38]. Other B-cell malignancies usually express CD22 more than CD25 [109]. Compared with CD19, CD22 was found to internalize more rapidly, making it a better target for a recombinant immunotoxin [84]. Finally, CD22 expressing normal B-cells can be replaced from precursor cells not expressing CD22 [110,111]. CD22 was therefore chosen as a target for recombinant immunotoxin development and BL22 was designed and produced [112,113]. BL22 (Figure 1) contains an Fv that binds to CD22, attached to PE38. [103,109,111,114]. BL22 was tested in phase 1 and 2 clinical trials and achieved CR rates of 47-61\% in patients with HCL [57-59]. BL22 was associated with hemolytic uremic syndrome (HUS), a side effect not seen with LMB-2. Fortunately, 
this type of HUS, which occurred in $12 \%$ and $5 \%$ of HCL patients treated in phase 1 and 2, respectively, was fully reversible and did not require plasmapheresis for complete resolution, indicating that its mechanism is different and less serious than HUS due to a Shiga-like toxin [115].

\section{Construction of Recombinant Immunotoxin Moxetumomab Pasudotox}

To enhance the activity and specificity of BL22, the complementarity determining region 3 (CDR3) hypervariable domain of BL22 underwent hot-spot mutagenesis. Using phage display selection, a mutant of BL22 was isolated containing THW instead of SSY at positions 100,100a, and 100b of the VH. This mutant has a 14-fold higher binding affinity to CD22 compared with BL22, mainly due to a slower off-rate [116]. This higher binding affinity causes an improvement in cytotoxicity toward both HCL and CLL. The new recombinant immunotoxin was initially named HA22, then CAT-8015, and finally, during clinical testing, moxetumomab pasudotox (Moxe). Preclinical studies included an animal study that showed improved antitumor activity of Moxe compared with BL22 [110]. With these data, phase 1 clinical testing of Moxe began in May of 2007, in relapsed/refractory HCL.

\section{Moxe Phase 1 Clinical Results}

The first 28 patients enrolled onto the phase I Moxe study in relapsed HCL included a dose-escalation cohort of 16 patients who received 5, 10, 20,30, and $40 \mu \mathrm{g} / \mathrm{kg}$ every other day for three doses $(\mathrm{QOD} \times 3)$ for each cycle with approximately 28 -day cycles. Twelve patients received $50 \mu \mathrm{g} / \mathrm{kg}$ [60]. Patients had received 1-7 (median 2) prior courses of purine analog and $11(46 \%)$ patients were refractory to their last course of purine analog defined as CR/PR $<1$ year. Seven had prior splenectomy and the other 21 had spleens with a median diameter of $150 \mathrm{~mm}$. Patients received 2-16 (median four) cycles. Thirteen (46\%) patients achieved CR, with an overall response rate (ORR) of $86 \%$. Of the 13 CRs, $10(77 \%)$ remained in CR at a median of 29 months of follow-up. The CR rate was not related to the number of prior courses of purine analog or to the duration of response to the last purine analog [60]. In contrast, $\mathrm{CR}$ rate was related to spleen status, in that patients with prior splenectomy $(\mathrm{N}=7)$ had no $\mathrm{CRs}$, while $13(62 \%)$ of 21 with spleens present up to $325 \mathrm{~mm}$ in diameter had CR ( $p=0.007)$. Our hypothesis for the lower CR rate in patients' post-splenectomy is that these patients have more advanced disease since splenectomy resolves cytopenias, requiring higher tumor infiltration into the bone marrow to result in cytopenias sufficient to qualify for treatment. We therefore recommend that patients receive Moxe prior to splenectomy. We did not observe dose-limiting toxicities (DLTs). HUS was observed in two patients with Moxe, but it was only of moderate (grade 2) severity, limited to grade 1 thrombocytopenia and grade 1 creatinine elevations. These two patients included one at 30 and one at $50 \mu \mathrm{g} / \mathrm{kg}$. Both patients fully recovered, and these mild laboratory abnormalities might not have been detected had the patients not been monitored carefully for HUS due to the experience with BL22. Few grade 3-4 toxicities were observed with Moxe, including grade 3-4 lymphopenia and leukopenia which probably represented treatment effects due to the targeting of malignant and normal CD22+ B-cells. Grade 1-2 toxicity included hypoalbuminemia, edema, weight gain, and proteinuria consistent with capillary leak syndrome (CLS). Hepatic enzyme elevation not associated with impaired hepatic function was also observed and even at grade 3 was not considered dose-limiting per protocol.

\section{Expansion of the Phase 1 Trial of Moxe}

To determine the clinical activity of Moxe at a fixed dose level, the phase I study was expanded to enroll 21 more patients at $50 \mu \mathrm{g} / \mathrm{kg}$, for a total of 49 phase 1 patients and a total of 33 at $50 \mu \mathrm{g} / \mathrm{kg}$, the peak dose level [64]. We did not observe additional cases of HUS in these additional 21 patients. With the 33 patients at $50 \mu \mathrm{g} / \mathrm{Kg} \times 3$ doses/cycle, we focused on MRD, assessed by bone marrow immunohistochemistry and blood and bone marrow aspirate flow cytometry. The detection limit was $0.002 \%$ by flow cytometry. Once achieving MRD-free CR, patients could receive two more cycles, called "consolidation" cycles. Figure 2 shows hematologic improvement and eradication of circulating 
HCL cells in the first patient treated at $50 \mu \mathrm{g} / \mathrm{Kg}$ QOD $\times 3$. This patient has remained in $\mathrm{CR}$ and is still MRD free at the 10.5-year time point after CR was first documented. Of 33 patients receiving $50 \mu \mathrm{g} / \mathrm{kg}$ QOD $\times 3$, the ORR was $88 \%$ and $21(64 \%)$ achieved CR. Twenty patients achieving CR were evaluable for MRD by all tests including bone marrow aspirate flow cytometry. Of these, 11 (55\%) achieved MRD-free CR and only one of these relapsed. The other 10 patients with MRD-free CR remained in CR with median $C R$ duration up to 72 months, median 42 months. Of nine patients with MRD+CR, eight relapsed, making median CR duration significantly prolonged for MRD-free vs. MRD+CR (not reached vs. 13.5 months $p<0.0001$ ). This was, to our knowledge, the first report that eradication of MRD in HCL is associated with longer CR duration. The duration of MRD-positive CR in this trial, which was for HCL patients in $\geq$ third line, was shorter than the duration of MRD-positive CR after first-line HCL treatment with cladribine [67]. We therefore believe it is particularly critical to eliminate MRD in multiply relapsed HCL.

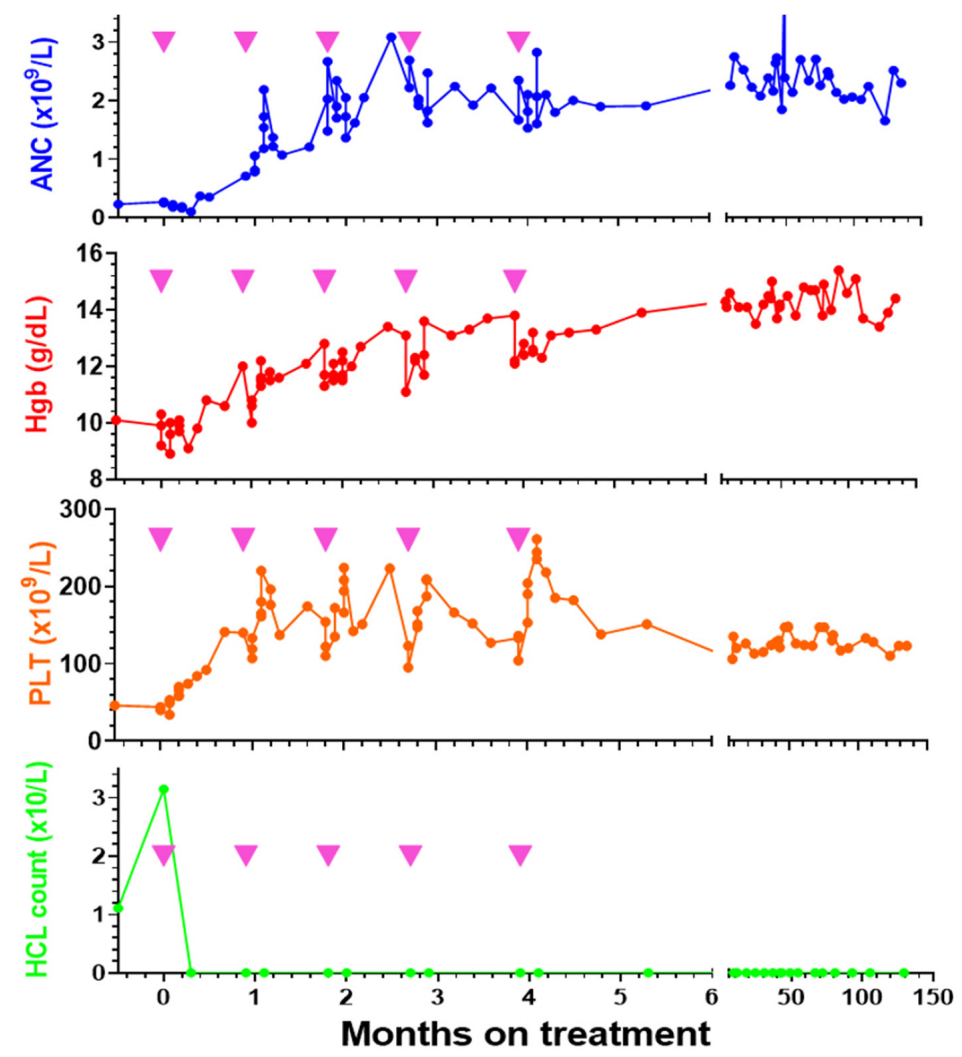

Figure 2. Patient $\mathrm{HH} 17$ was treated with Moxe $50 \mu \mathrm{g} / \mathrm{Kg}$ QOD $\times 3$ for 5 cycles, with the cycles indicated by the inverted pink triangles. Minimal residual disease (MRD)-free complete remission (CR) was achieved prior to cycle 4 , and the patient was still MRD-free by bone marrow immunohistochemistry and blood and bone marrow flow cytometry 129 months after treatment, 10.5 years in MRD-free CR.

\section{Pharmacokinetics of Moxe by Bioassay}

Since the toxin in Moxe is bacterial, we expected immunogenicity, but were surprised that in the phase 1 trial only 1 of 28 evaluable patients made high levels of neutralizing antibodies after the first cycle of Moxe [60]. This allowed most of the patients to be retreated to optimize response. The assay of neutralizing antibodies on the phase 1 trial involved incubating 200 and $1000 \mathrm{ng} / \mathrm{mL}$ mixtures of Moxe containing $90 \%$ patient serum for $15 \mathrm{~min}$ at $37{ }^{\circ} \mathrm{C}$ and comparing cytotoxic activity of these mixtures to those with the same concentration of Moxe incubated with albumin-containing saline. The cytotoxicity assay involved incubating dilutions of the mixtures with aliquots of CD22+ Raji cells and measuring inhibition of protein synthesis. To determine pharmacokinetics, dilutions of patient plasma after treatment were incubated with Raji cells and cytotoxicity compared to a standard curve 
made with purified Moxe. At the highest phase 1 dose level, 29 patients were evaluable by plasma for pharmacokinetic assays. These assays usually showed relatively low levels of Moxe during the first dose, due to the high CD22 density on tumor cells causing a CD22-sink [60]. Moxe achieved rapid tumor reductions during cycle 1 between the first and third doses, leading to a significant increase in peak level and area under the curve (AUC), and a decrease in volume of distribution (Vd) and clearance. On subsequent cycles, tumor burden remained diminished and the differences between the first (day 1) and third (day 5) doses were less pronounced.

\section{Antidrug Antibodies and Moxe Pharmacokinetics}

These Moxe phase 1 patients were also evaluated for antidrug antibodies (ADA), and 15 evaluable patients had $>50 \%$ neutralization of $200 \mathrm{ng} / \mathrm{mL}$ of Moxe prior to cycles $2(n=3), 3(n=5), 4(n=4)$, $5(n=2)$, and $6(n=1)$. This level of ADA disqualified the patients from subsequent cycles, but they received that "last" cycle since the ADA levels were not known until after cycle completion. In nearly all these extra cycles, peak levels and AUC increased and Vd and clearances decreased between days 1 and 5 [64]. This indicates that repeated doses of Moxe overcame neutralizing antibodies and that even secondary immunogenicity was insufficient to prevent cytotoxic and potentially therapeutic plasma levels of Moxe. Of these 15 patients, 9 went on to achieve CR. These data, together with the lack of toxicity during ADA development, justified repeat cycles of Moxe regardless of ADA, and hence justified not screening for ADA during phase 3 for eligibility or retreatment.

\section{Pivotal Phase 3 Testing of Moxe, Trial Design}

For the pivotal trial of Moxe that led to its FDA approval, Moxe was evaluated in a single-arm international multicenter phase 3 trial at 32 centers in 14 countries in patients with relapsed/refractory HCL [65]. Eligibility included at least two prior treatments including at least one course of purine analog, and additional treatment with either a second course of purine analog or rituximab or BRAF inhibitor. Patients required at least one cytopenia or symptomatic splenomegaly. Creatinine had to be $\leq 1.5 \mathrm{mg} / \mathrm{dL}$ or the estimated creatinine clearance had to be $\geq 60 \mathrm{~mL} / \mathrm{min}$. Exclusions included brain metastases and uncontrolled infection or organ failure. A total of 80 patients were enrolled and received Moxe at $40 \mu \mathrm{g} / \mathrm{kg}$ on days 1,3, and 5 in 28-day cycles for up to six cycles. Patients had to stop earlier than six cycles in the event of progressive disease, unacceptable toxicity, or documentation of MRD-free CR. The $40 \mu \mathrm{g} / \mathrm{kg}$ dose level during phase 3 was similar in potency to the $50 \mu \mathrm{g} / \mathrm{kg}$ dose level of phase 1 Moxe due to improvements in production and purity. Since patients had to stop retreatment after documentation of MRD-free CR, those who desired to receive the maximum number of cycles could not be restaged until after six cycles were complete. Thus, in the phase 3 trial, it was not possible to determine the number of consolidation cycles after MRD-negative CR. It should be noted that while MRD was assessed by bone marrow biopsy immunohistochemistry through a central lab, the assessment of MRD-negative CR for purposes of stopping retreatment was performed at each site, where the sensitivity of MRD tests likely differed. Since bone marrow aspirate flow cytometry is more sensitive than bone marrow biopsy immunohistochemistry [67], centers utilizing only the latter MRD test might have a higher rate of MRD-negative CR. The primary endpoint was to determine the percent of patients who could achieve $C R$, which required reversal of cytopenias to the level of a hematologic remission (HR), and then document absence of recurrent cytopenias (continued HR) over 180 days.

\section{Moxe Phase 3 Pivotal Trial Results}

Phase 1 and 3 results are compared in Table 2. A total of 89 patients were tested for eligibility and 80 patients were enrolled. Patient ages were 34-84 (median 60) years, patients had 2-11 (median 3) prior lines of therapy, and half of the patients had $\geq 3$ prior lines, evidence that this was a heavily pretreated population [65]. Of the 80 patients, $75 \%$ had prior rituximab, $29 \%$ had prior rituximab combined with purine analog, and $18 \%$ had a BRAF inhibitor. Fifty (63\%) patients completed all six cycles and 12 (15\%) received fewer than six cycles due to MRD-free CR. Another 12 (15\%) stopped early 
due to an adverse event and this was treatment-related in eight (10\%) patients. The median duration of follow-up was 16.7 months as of data cutoff in May of 2017. The CR rate was 41\% (33 of 80) for an ORR of 75\%. Durable CR over 180 days was achieved in 24 (30\%) of the patients at a median follow-up of 16.7 months. Thus, there were nine $(11 \%)$ patients who achieved CR but not durable CR. However, only two of these nine had recurrent cytopenias during the 180-day period of follow-up. Five of these nine patients actually did have durable $C R$, but the $C R$ began later than the end of treatment time point, so durable CR could not be documented at the time of the report. In the remaining two cases, patients decided to travel and were not able to complete the monthly blood counts over six months. Among the 33 (41\%) who achieved CR, 27 (82\%) were negative for MRD by immunohistochemistry. Of six patients with MRD-positive CR, the median CR duration was 5.9 months vs. not reached in the 27 patients with MRD-free CR [65]. Regarding safety, grade 3-4 treatment-related adverse events occurred in 13 (16\%) of the 80 patients including lymphopenia (30\%), HUS (5\%), infection (2.5\%), and CLS (2.5\%). All HUS and CLS events were reversible. Three patients (3.8\%) died of infection including pneumonia and sepsis, none of these related to Moxe. Based on the phase 1 and 3 trials, Moxe was approved by the FDA on 13 September 2018, under the name Lumoxiti, for patients with relapsed/refractory HCL who had received at least two prior systemic therapies, including treatment with a purine analog.

Table 2. Results of moxetumomab pasudotox (Moxe) during phase 1 and 3 testing.

\begin{tabular}{|c|c|c|}
\hline & Phase 1 & Phase 3 \\
\hline Patients treated & 49 & 80 \\
\hline Eligibility, clinical & $\begin{array}{c}\text { Cytopenias or } \\
\text { Symptomatic splenomegaly }\end{array}$ & $\begin{array}{c}\text { Cytopenias or } \\
\text { Symptomatic splenomegaly }\end{array}$ \\
\hline Eligibility, ADA & Negative test for ADA & Testing not needed \\
\hline Doses tested $(\mu \mathrm{g} / \mathrm{Kg}$ QOD $\times 3)$ & $\begin{array}{c}5,10,20, \text { and } 30(n=3 \text { each }) \\
40(n=4), 50(n=33)\end{array}$ & $40(\mathrm{n}=80)$ \\
\hline Patient ages & 40-77 (median 57) & 34-84 (median 60) \\
\hline Male-Female ratio & $41: 8$ & $68: 12$ \\
\hline HCLv & $2(4 \%)$ & $3(3.8 \%)$ \\
\hline \multicolumn{3}{|l|}{ Prior purine analog courses } \\
\hline 1 & $4(8 \%)$ & $10(13 \%)$ \\
\hline 2 & $24(49 \%)$ & $30(38 \%)$ \\
\hline$\geq 3$ & $21(43 \%)$ & $40(50 \%)$ \\
\hline Prior rituximab & $30(61 \%)$ & $60(75 \%)$ \\
\hline Prior splenectomy & $8(16 \%)$ & $5(6 \%)$ \\
\hline ORR & $42(86 \%)$ & $60(75 \%)$ \\
\hline CR rate & $28(57 \%)$ & $33(41 \%)$ \\
\hline Toxicity, dose level assessed & $50 \mu \mathrm{g} / \mathrm{Kg} \times 3(\mathrm{n}=33)$ & $40 \mu \mathrm{g} / \mathrm{Kg} \times 3(\mathrm{n}=80)$ \\
\hline \multicolumn{3}{|l|}{ Grades $1-4,3-4$} \\
\hline Hemolytic uremic syndrome & $2(4 \%), 0(0 \%)$ & $7(9 \%), 4(5 \%)$ \\
\hline Capillary leak syndrome & $8(16 \%), 0(0 \%)$ & $7(9 \%), 2(3 \%)$ \\
\hline
\end{tabular}

ADA, antidrug antibodies; ORR, overall response rate. The $50 \mu \mathrm{g} / \mathrm{Kg}$ phase 1 and $40 \mu \mathrm{g} / \mathrm{Kg}$ phase 3 doses had similar potency due to improvements in the manufacturing and purity of the phase 3 lot. 


\section{Mechanism and Prevention of HUS and CLS with Moxe}

In the phase 3 trial, the incidence of CLS and HUS of all grades was 5\% and 7.5\%, respectively [65]. In our experience with HUS from BL22 (seven cases) and Moxe (six cases) in HCL, HUS presented on day 7 or 8, i.e., 2-3 days after the last dose of Moxe given days 1,3, and 5, and never presented after day 8 [57-60,64,65]. For that reason, we recommend obtaining labs on day 8, looking for increases in creatinine, lactate dehydrogenase (LDH), and bilirubin, and decreases in platelets, hemoglobin, and haptoglobin. Abnormalities might be limited to grade 1 thrombocytopenia and creatinine elevation, but either of these alone on day 8 would not indicate HUS. Although the mechanism of immunotoxin-induced HUS is unknown, it is known that endothelial damage exposes ultra-large multimers of von Willebrand's factor under the endothelial surface which can constitute a site for platelet aggregation and thrombin formation [115]. CLS, which involves movement of fluid and protein out of the blood vessels, can result in intravascular volume depletion, an increase in Moxe concentration in the glomerular capillaries, and hence increase the risk of HUS. While CLS is a common effect of immunotoxins targeting a variety of antigens [55,56,117-123], HUS has only been reported from those targeting CD22 [57-60,64,65,80,81,124-126]. Immunohistochemistry studies showed no evidence that CD22 is expressed on glomerular endothelial cells which would be targeted specifically by Moxe. If that were the case, we could expect HUS to occur at lower doses of Moxe than of BL22, since Moxe binds with 14-fold improved affinity to CD22 [116]. Rather, we believe the Fv fragment of the Mab-targeting CD22 interacts, perhaps weakly, with a non-CD22 antigen present in the glomerulus. To prevent HUS, we advocate keeping the concentration of Moxe in the glomerulus as low as possible by ensuring adequate hydration. While excessive IV fluid can worsen CLS, leading to systemic and pulmonary edema, we find that oral hydration is highly effective without worsening CLS. Since CLS is constant, we recommend patients drink an average of about $250 \mathrm{~mL}$ ( $1 \mathrm{cup}$ ) of water every hour during days 1-8 of each cycle of Moxe, and not go more than 2-3 h at night without drinking. While this requires patient education and follow-up by the treating team [127], we find this is well tolerated, and in most patients does not cause hyponatremia. Some side effects occurring 6-24 h after Moxe, including headache, nausea, and fever, can lead to hypovolemia or decreased water intake, and these can be rapidly eliminated with dexamethasone $4 \mathrm{mg}$ orally. Most patients need oral dexamethasone after one or two of the three doses of Moxe, and some patients need none. Before using precautions of oral hydration and dexamethasone, three of our first nine patients enrolled on the phase 3 trial had grade 3 HUS, and after the precautions, only 1 of the next 17 patients had a grade 1 HUS ( $p=0.032$ for grade 3 HUS). While this was not a randomized comparison, we are using these precautions to improve the safety of Moxe and allow patients to receive a full 6 cycles to achieve MRD-free CR.

\section{ADA and Pharmacokinetics of Moxe during Phase 3 Testing}

To determine ADA and plasma levels during phase 3, ELISA assays rather than bioassays were utilized. Higher levels and more frequent positivity for ADA by ELISA were expected compared with ADA by bioassay. This is because ELISA is more sensitive and detects both neutralizing and non-neutralizing antibodies binding to Moxe, while the bioassay only detects neutralizing antibodies. ELISA assays detected a 59\% rate of ADA at baseline and $88 \%$ prevalence of ADA at least at one time point and increased as expected following treatment. An ELISA test was developed to determine ADA specificity for different domains of Moxe [128]. ADA at baseline was always associated with antibodies binding to the toxin domains of Moxe and these anti-toxin antibodies increased with treatment [128]. This was expected based the bacterial origin of PE38. While the median ADA titer increased with retreatment in all response groups, patients with $\mathrm{CR}$ had the lowest levels of ADA, followed by those achieving PR, stable disease, and progressive disease as best response, although statistical significance was not reported [65]. For 49 phase 1 and 74 phase 3 patients, pharmacokinetic data determined by ELISA were pooled to correlate with patient characteristics, disease burden, prior treatment, and ADA [129]. The model showed that the linear clearance from the central compartment after the first dose of Moxe in cycle 1 was $24.7 \mathrm{~L} / \mathrm{h}$, compared with $3.75 \mathrm{~L} / \mathrm{h}$ for subsequent doses. Patients with 
ADA titers $>10,240$ had 4-fold higher clearances than those with lower levels of ADA. While exposures higher than the median correlated with a higher response rate, CLS, and creatinine rises during phase 3, clinical benefit was observed even in patients with low exposure or high ADA. This showed that there is clinical activity of Moxe despite immunogenicity and resulting increased clearances [129].

\section{Further Development of Moxe for HCL}

To increase the rate of patients achieving MRD-free CR with Moxe, we are now testing Moxe in combination with rituximab. The rationale for this approach is two-fold. First, since rituximab depletes circulating B-cells to undetectable levels for about six months after the last dose, it may prevent ADA and improve drug exposure. Secondly, rituximab should reduce tumor burden, enabling Moxe to reach more tumor cells and achieve CR earlier. Even if rituximab does not decrease ADA and ADA increases after a certain number of cycles of Moxe, a faster response to Moxe due to the cell killing action of rituximab will increase the likelihood of MRD-free CR. It was reported that rituximab failed to prevent immunogenicity of LMB-1-targeting solid tumors [130]. Despite those results, rituximab may prevent ADA in patients with HCL since patients with B-cell malignancies have lower humoral immunity than patients with solid tumors, and since Moxe lacks the murine IgG constant domains of LMB-1 and should be less immunogenic. In the ongoing trial of Moxe-rituximab, the rituximab is begun on day-2, and Moxe on days 1, 3, and 5. The three-day interval between rituximab and Moxe on cycle 1 is designed to give rituximab enough time to reduce normal B-cells and the HCL burden. On subsequent cycles, spaced 28 days apart, rituximab is begun just prior to Moxe on day 1. Although rituximab is marginally effective in relapsed HCL as a single agent [131], we recently reported that its addition to first line cladribine results in a marked improvement in MRD-free CR, from 24\% to 97\% at six months [67]. In comparing Moxe-rituximab to cladribine-rituximab (CDAR), albeit across trials, it is notable that Moxe as a single-agent has a higher MRD-free CR rate than cladribine [64]. Vemurafenib, which did not eradicate MRD by immunohistochemistry as a single-agent [68], achieved an MRD-free CR rate of $65 \%$ in relapsed HCL when combined with rituximab [132], and the vemurafenib-obinutuzumab combination is currently being tested in first-line. We believe the Moxe-rituximab regimen, or possibly Moxe-obinutuzumab, may have potential in the future as a chemotherapy-free first-line treatment of HCL.

Funding: This research was funded by the Intramural Research Program, National Institutes of Health, Center for Cancer Research, National Institute of Cancer.

Acknowledgments: In this section you can acknowledge any support given which is not covered by the author contribution or funding sections. This may include administrative and technical support, or donations in kind (e.g., materials used for experiments).

Conflicts of Interest: Both R.K. and I.P. have patents assigned to the National Institutes of Health.

\section{References}

1. Bouroncle, B.A.; Wiseman, B.K.; Doan, C.A. Leukemic reticuloendotheliosis. Blood 1958, 13, 609-630. [CrossRef] [PubMed]

2. Bouroncle, B.A. Leukemic reticuloendotheliosis (hairy cell leukemia). Blood 1979, 53, 412-436. [CrossRef] [PubMed]

3. Siegel, R.L.; Miller, K.D.; Jemal, A. Cancer statistics, 2020. CA Cancer J. Clin. 2020, 70, 7-30. [CrossRef] [PubMed]

4. Tiacci, E.; Trifonov, V.; Schiavoni, G.; Holmes, A.; Kern, W.; Martelli, M.P.; Pucciarini, A.; Bigerna, B.; Pacini, R.; Wells, V.A.; et al. BRAF mutations in hairy-cell leukemia. N. Engl. J. Med. 2011, 364, 2305-2315. [CrossRef]

5. Tiacci, E.; Schiavoni, G.; Forconi, F.; Santi, A.; Trentin, L.; Ambrosetti, A.; Cecchini, D.; Sozzi, E.; Francia di Celle, P.; Di Bello, C.; et al. Simple genetic diagnosis of hairy cell leukemia by sensitive detection of the BRAF-V600E mutation. Blood 2012, 119, 192-195. [CrossRef]

6. Tiacci, E.; Pettirossi, V.; Schiavoni, G.; Falini, B. Genomics of Hairy Cell Leukemia. J. Clin. Oncol. 2017, 35, 1002-1010. [CrossRef] 
7. Xi, L.; Arons, E.; Navarro, W.; Calvo, K.R.; Stetler-Stevenson, M.; Raffeld, M.; Kreitman, R.J. Both variant and IGHV4-34-expressing hairy cell leukemia lack the BRAF V600E mutation. Blood 2012, 119, 3330-3332. [CrossRef]

8. Durham, B.H.; Getta, B.; Dietrich, S.; Taylor, J.; Won, H.; Bogenberger, J.M.; Scott, S.; Kim, E.; Chung, Y.R.; Chung, S.S.; et al. Genomic analysis of hairy cell leukemia identifies novel recurrent genetic alterations. Blood 2017, 130, 1644-1648. [CrossRef]

9. Maitre, E.; Bertrand, P.; Maingonnat, C.; Viailly, P.J.; Wiber, M.; Naguib, D.; Salaun, V.; Cornet, E.; Damaj, G.; Sola, B.; et al. New generation sequencing of targeted genes in the classical and the variant form of hairy cell leukemia highlights mutations in epigenetic regulation genes. Oncotarget 2018, 9, 28866-28876. [CrossRef]

10. Weston-Bell, N.J.; Tapper, W.; Gibson, J.; Bryant, D.; Moreno, Y.; John, M.; Ennis, S.; Kluin-Nelemans, H.C.; Collins, A.R.; Sahota, S.S. Exome Sequencing in Classic Hairy Cell Leukaemia Reveals Widespread Variation in Acquired Somatic Mutations between Individual Tumours Apart from the Signature BRAF V(600)E Lesion. PLoS ONE 2016, 11, e0149162. [CrossRef]

11. Green-Lott, A.M.; Singaraju, R.; Liu, M.L.; Ascensao, J. Hairy Cell Leukemia and Ground Water Contamination with Industrial Solvents: A Case Report. Mil. Med. 2020. [CrossRef]

12. Aristeguieta, C.; de Perio, M.A. Three cases of hairy cell leukemia in coal miners. Leuk. Lymphoma 2011, 52, 2391-2392. [CrossRef]

13. Hardell, L.; Eriksson, M.; Nordstrom, M. Exposure to pesticides as risk factor for non-Hodgkin's lymphoma and hairy cell leukemia: Pooled analysis of two Swedish case-control studies. Leuk. Lymphoma 2002, 43, 1043-1049. [CrossRef] [PubMed]

14. Paydas, S. Hairy cell leukemia and bladder cancer in a patient: Relation with dye exposure and review of the literaure. Adv. Hematol. 2009, 2009, 812960. [CrossRef] [PubMed]

15. Tadmor, T.; Polliack, A. Epidemiology and environmental risk in hairy cell leukemia. Best Pract. Res. Clin. Haematol. 2015, 28, 175-179. [CrossRef]

16. Golomb, H.M.; Catovsky, D.; Golde, D.W. Hairy cell leukemia: A clinical review based on 71 cases. Ann. Intern. Med. 1978, 89, 677-683. [CrossRef]

17. Spiers, A.S.; Moore, D.; Cassileth, P.A.; Harrington, D.P.; Cummings, F.J.; Neiman, R.S.; Bennett, J.M.; MJ, O.C. Remissions in hairy-cell leukemia with pentostatin (2'-deoxycoformycin). N. Engl. J. Med. 1987, 316, 825-830. [CrossRef] [PubMed]

18. Johnston, J.B.; Glazer, R.I.; Pugh, L.; Israels, L.G. The treatment of hairy-cell leukaemia with 2'-deoxycoformycin. Br. J. Haematol. 1986, 63, 525-534. [CrossRef]

19. Grever, M.; Kopecky, K.; Foucar, M.K.; Head, D.; Bennett, J.M.; Hutchison, R.E.; Corbett, W.E.; Cassileth, P.A.; Habermann, T.; Golomb, H.; et al. Randomized comparison of pentostatin versus interferon alfa-2a in previously untreated patients with hairy cell leukemia: An intergroup study. J. Clin. Oncol. 1995, 13, 974-982. [CrossRef]

20. Piro, L.D.; Carrera, C.J.; Carson, D.A.; Beutler, E. Lasting remissions in hairy-cell leukemia induced by a single infusion of 2-chlorodeoxyadenosine. N. Engl. J. Med. 1990, 322, 1117-1121. [CrossRef]

21. Saven, A.; Burian, C.; Koziol, J.A.; Piro, L.D. Long-term follow-up of patients with hairy cell leukemia after cladribine treatment. Blood 1998, 92, 1918-1926. [CrossRef] [PubMed]

22. Robak, T.; Blasinska-Morawiec, M.; Blonski, J.; Hellmann, A.; Halaburda, K.; Konopka, L.; Kotlarek-Haus, S.; Potoczek, S.; Hansz, J.; Dmoszynska, A.; et al. 2-chlorodeoxyadenosine (cladribine) in the treatment of hairy cell leukemia and hairy cell leukemia variant: 7-year experience in Poland. Eur. J. Haematol. 1999, 62, 49-56. [CrossRef] [PubMed]

23. Else, M.; Dearden, C.E.; Matutes, E.; Garcia-Talavera, J.; Rohatiner, A.Z.; Johnson, S.A.; O'Connor, N.T.; Haynes, A.; Osuji, N.; Forconi, F.; et al. Long-term follow-up of 233 patients with hairy cell leukaemia, treated initially with pentostatin or cladribine, at a median of 16 years from diagnosis. Br. J. Haematol. 2009, 145, 733-740. [CrossRef]

24. Goodman, G.R.; Beutler, E.; Saven, A. Cladribine in the treatment of hairy-cell leukaemia. Best Pract. Res. Clin. Haematol. 2003, 16, 101-116. [CrossRef]

25. Flinn, I.W.; Kopecky, K.J.; Foucar, M.K.; Head, D.; Bennett, J.M.; Hutchison, R.E.; Corbett, W.E.N.; Cassileth, P.A.; Habermann, T.; Golomb, H.; et al. Long-term results in hairy cell leukemia treated with pentostatin. Proc. Am. Soc. Clin. Oncol. 1997, 90 (Suppl. 1), 578a. 
26. Wierda, W.G.; Byrd, J.C.; Abramson, J.S.; Bhat, S.; Bociek, G.; Brander, D.; Brown, J.; Chanan-Khan, A.; Coutre, S.E.; Davis, R.S.; et al. Hairy Cell Leukemia, Version 2.2018, NCCN Clinical Practice Guidelines in Oncology. J. Natl. Compr. Cancer Netw. 2017, 15, 1414-1427. [CrossRef] [PubMed]

27. Grever, M.R.; Abdel-Wahab, O.; Andritsos, L.A.; Banerji, V.; Barrientos, J.; Blachly, J.S.; Call, T.G.; Catovsky, D.; Dearden, C.; Demeter, J.; et al. Consensus Guidelines for the Diagnosis and Management of Patients with Classic Hairy Cell Leukemia. Blood 2017, 129, 553-560. [CrossRef]

28. Seymour, J.F.; Kurzrock, R.; Freireich, E.J.; Estey, E.H. 2-chlorodeoxyadenosine induces durable remissions and prolonged suppression of CD4+ lymphocyte counts in patients with hairy cell leukemia. Blood 1994, 83, 2906-2911. [CrossRef]

29. Seymour, J.F.; Talpaz, M.; Kurzrock, R. Response duration and recovery of CD4+ lymphocytes following deoxycoformycin in interferon-alpha-resistant hairy cell leukemia: 7- year follow-up. Leukemia 1997, 11, 42-47. [CrossRef]

30. Tadmor, T. Purine analog toxicity in patients with hairy cell leukemia. Leuk. Lymphoma 2011, 52 (Suppl. 2), 38-42. [CrossRef]

31. Cheson, B.D.; Vena, D.A.; Foss, F.M.; Sorensen, J.M. Neurotoxicity of purine analogs: A review. J. Clin. Oncol. 1994, 12, 2216-2228. [CrossRef] [PubMed]

32. Getta, B.M.; Woo, K.M.; Devlin, S.; Park, J.H.; Abdel-Wahab, O.; Saven, A.; Rai, K.; Tallman, M.S. Treatment outcomes and secondary cancer incidence in young patients with hairy cell leukaemia. Br. J. Haematol. 2016, 175, 402-409. [CrossRef] [PubMed]

33. Arons, E.; Suntum, T.; Stetler-Stevenson, M.; Kreitman, R.J. VH4-34+ hairy cell leukemia, a new variant with poor prognosis despite standard therapy. Blood 2009, 114, 4687-4695. [CrossRef] [PubMed]

34. Kreitman, R.J.; Wilson, W.; Calvo, K.R.; Arons, E.; Roth, L.; Sapolsky, J.; Zhou, H.; Raffeld, M.; Stetler-Stevenson, M. Cladribine with immediate rituximab for the treatment of patients with variant hairy cell leukemia. Clin. Cancer Res. 2013, 19, 6873-6881. [CrossRef]

35. Matutes, E.; Martinez-Trillos, A.; Campo, E. Hairy cell leukaemia-variant: Disease features and treatment. Best Pract. Res. Clin. Haematol. 2015, 28, 253-263. [CrossRef]

36. Quest, G.R.; Johnston, J.B. Clinical features and diagnosis of hairy cell leukemia. Best Pract. Res. Clin Haematol. 2015, 28, 180-192. [CrossRef]

37. Bigorra, L.; Larriba, I.; Gutierrez-Gallego, R. The hairy cell leukaemia oxymoron: Monocytotic monocytopenia. Clin. Chem. Lab. Med. 2020. [CrossRef]

38. Shao, H.; Calvo, K.R.; Grönborg, M.; Tembhare, P.R.; Kreitman, R.J.; Stetler-Stevenson, M.; Yuan, C.M. Distinguishing Hairy Cell Leukemia Variant from Hairy Cell Leukemia: Development and Validation of Diagnostic Criteria. Leuk. Res. 2013, 37, 401-409. [CrossRef]

39. Wotherspoon, A.; Attygalle, A.; Mendes, L.S. Bone marrow and splenic histology in hairy cell leukaemia. Best Pract. Res. Clin. Haematol. 2015, 28, 200-207. [CrossRef]

40. Gupta, G.K.; Sun, X.; Yuan, C.M.; Stetler-Stevenson, M.; Kreitman, R.J.; Maric, I. The Usefulness of Novel Dual Color Immunohistochemistry in Detection of Minimal Hairy Cell Leukemia in Bone Marrow. Am. J. Clin. Pathol. 2019, 153, 322-327. [CrossRef]

41. Guerrini, F.; Paolicchi, M.; Ghio, F.; Ciabatti, E.; Grassi, S.; Salehzadeh, S.; Ercolano, G.; Metelli, M.R.; Del Re, M.; Iovino, L.; et al. The Droplet Digital PCR: A New Valid Molecular Approach for the Assessment of B-RAF V600E Mutation in Hairy Cell Leukemia. Front. Pharmacol. 2016, 7, 363. [CrossRef] [PubMed]

42. Arons, E.; Adams, S.; Pastan, I.; Kreitman, R.J. Class II human leukocyte antigen DRB1*11 in hairy cell leukaemia patients with and without haemolytic uremic syndrome. Br. J. Haematol. 2014, 166, 729-738. [CrossRef] [PubMed]

43. Cawley, J.C.; Burns, G.F.; Hayhoe, F.G. A chronic lymphoproliferative disorder with distinctive features: A distinct variant of hairy-cell leukaemia. Leuk. Res. 1980, 4, 547-559. [CrossRef]

44. Matutes, E. Immunophenotyping and differential diagnosis of hairy cell leukemia. Hematol. Oncol. Clin. N. Am. 2006, 20, 1051-1063. [CrossRef] [PubMed]

45. Ravandi, F.; O’Brien, S.; Jorgensen, J.; Pierce, S.; Faderl, S.; Ferrajoli, A.; Koller, C.; Challagundla, P.; York, S.; Brandt, M.; et al. Phase 2 study of cladribine followed by rituximab in patients with hairy cell leukemia. Blood 2011, 118, 3818-3823. [CrossRef] [PubMed] 
46. Matutes, E.; Oscier, D.; Montalban, C.; Berger, F.; CalletBauchu, E.; Dogan, A.; Felman, P.; Franco, V.; Iannitto, E.; Mollejo, M.; et al. Splenic marginal zone lymphoma proposals for a revision of diagnostic, staging and therapeutic criteria. Leukemia 2008, 22, 487-495. [CrossRef]

47. Jain, P.; Ok, C.Y.; Konoplev, S.; Patel, K.P.; Jorgensen, J.; Estrov, Z.; Luthra, R.; Kantarjian, H.; Ravandi, F. Relapsed Refractory BRAF-Negative, IGHV4-34-Positive Variant of Hairy Cell Leukemia: A Distinct Entity? J. Clin. Oncol. 2016, 34, e57-e60. [CrossRef]

48. Arons, E.; Kreitman, R.J. Molecular variant of hairy cell leukemia with poor prognosis. Leuk. Lymphoma 2011, 52 (Suppl. 2), 99-102. [CrossRef]

49. Poret, N.; Fu, Q.; Guihard, S.; Cheok, M.; Miller, K.; Zeng, G.; Quesnel, B.; Troussard, X.; Galiegue-Zouitina, S.; Shelley, C.S. CD38 in Hairy Cell Leukemia Is a Marker of Poor Prognosis and a New Target for Therapy. Cancer Res. 2015, 75, 3902-3911. [CrossRef]

50. Jain, D.; Dorwal, P.; Gajendra, S.; Pande, A.; Mehra, S.; Sachdev, R. CD5 positive hairy cell leukemia: A rare case report with brief review of literature. Cytom. B Clin. Cytom. 2016, 90, 467-472. [CrossRef]

51. Shackelford, R.E.; Heldmann, M.; Eskandari, F.; Joshi, N.; Browning, J.; Maxwell, N.; Coteligam, J. Marked retroperitoneal lymphadenopathy in hairy cell leukemia: A case report. Case Rep. Oncol. 2013, 6, 493-496. [CrossRef]

52. Cortazar, J.M.; DeAngelo, D.J.; Pinkus, G.S.; Morgan, E.A. Morphological and immunophenotypical features of hairy cell leukaemia involving lymph nodes and extranodal tissues. Histopathology 2017, 71, 112-124. [CrossRef]

53. Wang, L.; Tadros, A.S.; Hoh, C.K.; Wang, H.Y. CD10-Positive Hairy Cell Leukemia Involving Multiple Deep Lymph Nodes. Clin. Lymphoma Myeloma Leuk. 2016, 16, e51-e53. [CrossRef] [PubMed]

54. Tallman, M.S.; Hakimian, D.; Rademaker, A.W.; Zanzig, C.; Wollins, E.; Rose, E.; Peterson, L.C. Relapse of hairy cell leukemia after 2-chlorodeoxyadenosine: Long-term follow-up of the Northwestern University experience. Blood 1996, 88, 1954-1959. [CrossRef] [PubMed]

55. Kreitman, R.J.; Wilson, W.H.; Robbins, D.; Margulies, I.; Stetler-Stevenson, M.; Waldmann, T.A.; Pastan, I. Responses in refractory hairy cell leukemia to a recombinant immunotoxin. Blood 1999, 94, 3340-3348. [CrossRef] [PubMed]

56. Kreitman, R.J.; Wilson, W.H.; White, J.D.; Stetler-Stevenson, M.; Jaffe, E.S.; Waldmann, T.A.; Pastan, I. Phase I trial of recombinant immunotoxin Anti-Tac(Fv)-PE38 (LMB-2) in patients with hematologic malignancies. J. Clin. Oncol. 2000, 18, 1614-1636. [CrossRef]

57. Kreitman, R.J.; Wilson, W.H.; Bergeron, K.; Raggio, M.; Stetler-Stevenson, M.; FitzGerald, D.J.; Pastan, I. Efficacy of the Anti-CD22 Recombinant Immunotoxin BL22 in Chemotherapy-Resistant Hairy-Cell Leukemia. New Engl. J. Med. 2001, 345, 241-247. [CrossRef]

58. Kreitman, R.J.; Squires, D.R.; Stetler-Stevenson, M.; Noel, P.; Fitzgerald, D.J.; Wilson, W.H.; Pastan, I. Phase I trial of recombinant immunotoxin RFB4(dsFv)-PE38 (BL22) in patients with B-cell malignancies. J. Clin. Oncol. 2005, 23, 6719-6729. [CrossRef]

59. Kreitman, R.J.; Stetler-Stevenson, M.; Margulies, I.; Noel, P.; FitzGerald, D.J.P.; Wilson, W.H.; Pastan, I. Phase II trial of recombinant immunotoxin RFB4(dsFv)-PE38 (BL22) in patients with hairy cell leukemia. J. Clin. Oncol. 2009, 27, 2983-2990. [CrossRef]

60. Kreitman, R.J.; Tallman, M.S.; Robak, T.; Coutre, S.; Wilson, W.H.; Stetler-Stevenson, M.; FitzGerald, D.J.; Lechleider, R.; Pastan, I. Phase I trial of anti-CD22 recombinant immunotoxin moxetumomab pasudotox (CAT-8015 or HA22) in patients with hairy cell leukemia. J. Clin. Oncol. 2012, 30, 1822-1828. [CrossRef]

61. Resolution Consensus. Consensus resolution: Proposed criteria for evaluation of response to treatment in hairy cell leukemia. Leukemia 1987, 1, 405.

62. Cheson, B.D.; Sorensen, J.M.; Vena, D.A.; Montello, M.J.; Barrett, J.A.; Damasio, E.; Tallman, M.; Annino, L.; Connors, J.; Coiffier, B.; et al. Treatment of hairy cell leukemia with 2-chlorodeoxyadenosine via the Group C protocol mechanism of the National Cancer Institute: A report of 979 patients. J. Clin. Oncol. 1998, 16, 3007-3015. [CrossRef] [PubMed]

63. Chadha, P.; Rademaker, A.W.; Mendiratta, P.; Kim, B.; Evanchuk, D.M.; Hakimian, D.; Peterson, L.C.; Tallman, M.S. Treatment of hairy cell leukemia with 2-chlorodeoxyadenosine (2-CdA): Long-term follow-up of the Northwestern University experience. Blood 2005, 106, 241-246. [CrossRef] [PubMed] 
64. Kreitman, R.J.; Tallman, M.S.; Robak, T.; Coutre, S.; Wilson, W.H.; Stetler-Stevenson, M.; FitzGerald, D.J.; Santiago, L.; Gao, G.; Lanasa, M.C.; et al. Minimal residual hairy cell leukemia eradication with moxetumomab pasudotox: Phase 1 results and long-term follow-up. Blood 2018, 131, 2331-2334. [CrossRef] [PubMed]

65. Kreitman, R.J.; Dearden, C.; Zinzani, P.L.; Delgado, J.; Karlin, L.; Robak, T.; Gladstone, D.E.; le Coutre, P.; Dietrich, S.; Gotic, M.; et al. Moxetumomab Pasudotox in Relapsed/Refractory Hairy Cell Leukemia. Leukemia 2018, 32, 1768-1777. [CrossRef]

66. Burotto, M.; Stetler-Stevenson, M.; Arons, E.; Zhou, H.; Wilson, W.; Kreitman, R.J. Bendamustine and Rituximab in Relapsed and Refractory Hairy Cell Leukemia. Clin. Cancer Res. 2013, 19, 6313-6321. [CrossRef]

67. Chihara, D.; Arons, E.; Stetler-Stevenson, M.; Yuan, C.; Wang, H.; Zhou, H.; Raffeld, M.; Xi, L.; Steinberg, S.M.; Feurtado, J.; et al. Randomized phase II study of 1st-line cladribine with concurrent or delayed rituximab in patients with hairy cell leukemia. J. Clin. Oncol. 2020, in press. [CrossRef]

68. Tiacci, E.; Park, J.H.; De Carolis, L.; Chung, S.S.; Broccoli, A.; Scott, S.; Zaja, F.; Devlin, S.; Pulsoni, A.; Chung, Y.R.; et al. Targeting Mutant BRAF in Relapsed or Refractory Hairy-Cell Leukemia. New Engl. J. Med. 2015, 373, 1733-1747. [CrossRef]

69. Sarid, N.; Ahmad, H.N.; Wotherspoon, A.; Dearden, C.E.; Else, M.; Catovsky, D. An unusual indication for splenectomy in hairy cell leukaemia: A report of three cases with persistent splenomegaly after chemoimmunotherapy. Br. J. Haematol. 2015, 171, 784-787. [CrossRef]

70. Matsushita, K.; Margulies, I.; Onda, M.; Nagata, S.; Stetler-Stevenson, M.; Kreitman, R.J. Soluble CD22 as a Tumor Marker for Hairy Cell Leukemia. Blood 2008, 112, 2272-2277. [CrossRef]

71. Kreitman, R.J. Immunoconjugates and new molecular targets in hairy cell leukemia. Hematol. Am. Soc. Hematol. Educ. Program. 2012, 2012, 660-666. [CrossRef]

72. Tallman, M.S.; Hakimian, D.; Kopecky, K.J.; Wheaton, S.; Wollins, E.; Foucar, K.; Cassileth, P.A.; Habermann, T.; Grever, M.; Rowe, J.M.; et al. Minimal residual disease in patients with hairy cell leukemia in complete remission treated with 2-chlorodeoxyadenosine or 2- deoxycoformycin and prediction of early relapse. Clin. Cancer Res. 1999, 5, 1665-1670. [PubMed]

73. Chihara, D.; Kreitman, R.J. Treatment of Hairy cell leukemia. Exp. Rev. Hematol. 2020, submitted.

74. Kreitman, R.J.; Pastan, I. Antibody fusion proteins: Anti-CD22 recombinant immunotoxin moxetumomab pasudotox. Clin. Cancer Res. 2011, 17, 6398-6405. [CrossRef] [PubMed]

75. Pastan, I.; Hassan, R.; FitzGerald, D.J.P.; Kreitman, R.J. Immunotoxin therapy of cancer. Nat. Rev. Cancer 2006, 6, 559-565. [CrossRef]

76. Kreitman, R.J.; Pastan, I. Immunotoxins in the treatment of refractory hairy cell leukemia. Hematol. Oncol. Clin. N. Am. 2006, 20, 1137-1151. [CrossRef]

77. Endo, Y.; Mitsui, K.; Motizuki, M.; Tsurugi, K. The mechanism of action of ricin and related toxic lectins on eukaryotic ribosomes. J. Biol. Chem. 1987, 262, 5908-5912.

78. Yamaizumi, M.; Mekada, E.; Uchida, T.; Okada, Y. One molecule of diphtheria toxin fragment A introduced into a cell can kill the cell. Cell 1978, 15, 245-250. [CrossRef]

79. Du, X.; Youle, R.J.; FitzGerald, D.J.; Pastan, I. Pseudomonas exotoxin A-mediated apoptosis is Bak dependent and preceded by the degradation of Mcl-1. Mol. Cell Biol. 2010, 30, 3444-3452. [CrossRef]

80. Messmann, R.A.; Vitetta, E.S.; Headlee, D.; Senderowicz, A.M.; Figg, W.D.; Schindler, J.; Michiel, D.F.; Creekmore, S.; Steinberg, S.M.; Kohler, D.; et al. A phase I study of combination therapy with immunotoxins IgG-HD37- deglycosylated ricin A chain (dgA) and IgG-RFB4-dgA (Combotox) in patients with refractory CD19(+), CD22(+) B cell lymphoma. Clin. Cancer Res. 2000, 6, 1302-1313.

81. Amlot, P.L.; Stone, M.J.; Cunningham, D.; Fay, J.; Newman, J.; Collins, R.; May, R.; McCarthy, M.; Richardson, J.; Ghetie, V.; et al. A phase I study of an anti-CD22-deglycosylated ricin A chain immunotoxin in the treatment of B-cell lymphomas resistant to conventional therapy. Blood 1993, 82, 2624-2633. [CrossRef] [PubMed]

82. Kreitman, R.J. Getting plant toxins to fuse. Leuk. Res. 1997, 21, 997-999. [CrossRef]

83. Bacha, P.; Williams, D.P.; Waters, C.; Williams, J.M.; Murphy, J.R.; Strom, T.B. Interleukin 2 receptor-targeted cytotoxicity: Interleukin 2 receptor-mediated action of a diphtheria toxin-related interleukin 2 fusion protein. J. Exp. Med. 1988, 167, 612-622. [CrossRef] [PubMed]

84. Du, X.; Beers, R.; FitzGerald, D.J.; Pastan, I. Differential cellular internalization of anti-CD19 and-CD22 immunotoxins results in different cytotoxic activity. Cancer Res. 2008, 68, 6300-6305. [CrossRef] [PubMed] 
85. Ogata, M.; Fryling, C.M.; Pastan, I.; FitzGerald, D.J. Cell-mediated cleavage of Pseudomonas exotoxin between $\mathrm{Arg}^{279}$ and Gly ${ }^{280}$ generates the enzymatically active fragment which translocates to the cytosol. J. Biol. Chem. 1992, 267, 25396-25401.

86. Fryling, C.; Ogata, M.; FitzGerald, D. Characterization of a cellular protease that cleaves Pseudomonas exotoxin. Infect. Immun. 1992, 60, 497-502. [CrossRef]

87. Chiron, M.F.; Fryling, C.M.; FitzGerald, D.J. Cleavage of Pseudomonas exotoxin and diphtheria toxin by a furin-like enzyme prepared from beef liver. J. Biol. Chem. 1994, 269, 18167-18176.

88. McKee, M.L.; FitzGerald, D.J. Reduction of furin-nicked Pseudomonas exotoxin A: An unfolding story. Biochemistry 1999, 38, 16507-16513. [CrossRef]

89. Kreitman, R.J.; Pastan, I. Importance of the glutamate residue of KDEL in increasing the cytotoxicity of Pseudomonas exotoxin derivatives and for increased binding to the KDEL receptor. Biochem. J. 1995, 307, 29-37. [CrossRef]

90. Hessler, J.L.; Kreitman, R.J. An early step in Pseudomonas exotoxin action is removal of the terminal lysine residue, which allows binding to the KDEL receptor. Biochemistry 1997, 36, 14577-14582. [CrossRef]

91. Theuer, C.; Kasturi, S.; Pastan, I. Domain II of Pseudomonas exotoxin A arrests the transfer of translocating nascent chains into mammalian microsomes. Biochemistry 1994, 33, 5894-5900. [CrossRef] [PubMed]

92. Theuer, C.P.; Buchner, J.; FitzGerald, D.; Pastan, I. The N-terminal region of the 37-kDa translocated fragment of Pseudomonas exotoxin A aborts translocation by promoting its own export after microsomal membrane insertion. Proc. Natl. Acad. Sci. USA 1993, 90, 7774-7778. [CrossRef] [PubMed]

93. Webb, T.R.; Cross, S.H.; McKie, L.; Edgar, R.; Vizor, L.; Harrison, J.; Peters, J.; Jackson, I.J. Diphthamide modification of eEF2 requires a J-domain protein and is essential for normal development. J. Cell Sci. 2008, 121, 3140-3145. [CrossRef] [PubMed]

94. Carroll, S.F.; Collier, R.J. Active site of Pseudomonas aeruginosa exotoxin A. Glutamic acid 553 is photolabeled by NAD and shows functional homology with glutamic acid 148 of diphtheria toxin. J. Biol. Chem. 1987, 262, 8707-8711. [PubMed]

95. Brinkmann, U.; Brinkmann, E.; Gallo, M.; Pastan, I. Cloning and characterization of a cellular apoptosis susceptibility gene, the human homologue to the yeast chromosome segregation gene CSE1. Proc. Natl. Acad. Sci. USA 1995, 92, 10427-10431. [CrossRef]

96. Keppler-Hafkemeyer, A.; Kreitman, R.J.; Pastan, I. Apoptosis induced by immunotoxins used in the treatment of hematologic malignancies. Int. J. Cancer 2000, 87, 86-94. [CrossRef]

97. Decker, T.; Oelsner, M.; Kreitman, R.J.; Salvatore, G.; Wang, Q.C.; Pastan, I.; Peschel, C.; Licht, T. Induction of Caspase-Dependent Programmed Cell Death in B-Cell Chronic Lymphocytic Leukemia Cells by Anti-CD22 Immunotoxins. Blood 2004, 103, 2718-2726. [CrossRef]

98. Antignani, A.; Segal, D.; Simon, N.; Kreitman, R.J.; Huang, D.; FitzGerald, D.J. Essential Role for Bim in mediating the apoptotic and anti-tumor activities of immunotoxins. Oncogene 2017, 36, 4953-4962. [CrossRef]

99. Chaudhary, V.K.; Queen, C.; Junghans, R.P.; Waldmann, T.A.; FitzGerald, D.J.; Pastan, I. A recombinant immunotoxin consisting of two antibody variable domains fused to Pseudomonas exotoxin. Nature 1989, 339, 394-397. [CrossRef]

100. Kreitman, R.J.; Batra, J.K.; Seetharam, S.; Chaudhary, V.K.; FitzGerald, D.J.; Pastan, I. Single-chain immunotoxin fusions between anti-Tac and Pseudomonas exotoxin: Relative importance of the two toxin disulfide bonds. Bioconj. Chem. 1993, 4, 112-120. [CrossRef]

101. Kreitman, R.J.; Chaudhary, V.K.; Waldmann, T.; Willingham, M.C.; FitzGerald, D.J.; Pastan, I. The recombinant immunotoxin anti-Tac(Fv)-Pseuodomonas exotoxin 40 is cytotoxic toward peripheral blood malignant cells from patients with adult T-cell leukemia. Proc. Natl. Acad. Sci. USA 1990, 87, 8291-8295. [CrossRef] [PubMed]

102. Shen, G.; Li, J.; Ghetie, M.; Ghetie, V.; May, R.D.; Till, M.; Brown, A.N.; Relf, M.; Knowles, P.; Uhr, J.W.; et al. Evaluation of four CD22 antibodies as ricin A chain-containing immunotoxins for the in vivo therapy of human B-cell leukemias and lymphomas. Int. J. Cancer 1988, 42, 792-797. [CrossRef] [PubMed]

103. Mansfield, E.; Amlot, P.; Pastan, I.; FitzGerald, D.J. Recombinant RFB4 immunotoxins exhibit potent cytotoxic activity for CD22-bearing cells and tumors. Blood 1997, 90, 2020-2026. [CrossRef] [PubMed]

104. Kreitman, R.J.; Bailon, P.; Chaudhary, V.K.; FitzGerald, D.J.P.; Pastan, I. Recombinant immunotoxins containing anti- $\mathrm{Tac}(\mathrm{Fv})$ and derivatives of Pseudomonas exotoxin produce complete regression in mice of an interleukin-2 receptor-expressing human carcinoma. Blood 1994, 83, 426-434. [CrossRef] [PubMed] 
105. Kreitman, R.J.; Chaudhary, V.K.; Waldmann, T.A.; Hanchard, B.; Cranston, B.; FitzGerald, D.J.P.; Pastan, I. Cytotoxic activities of recombinant immunotoxins composed of Pseudomonas toxin or diphtheria toxin toward lymphocytes from patients with adult T-cell leukemia. Leukemia 1993, 7, 553-562.

106. Robbins, D.H.; Margulies, I.; Stetler-Stevenson, M.; Kreitman, R.J. Hairy cell leukemia, a B-cell neoplasm which is particularly sensitive to the cytotoxic effect of anti-Tac(Fv)-PE38 (LMB-2). Clin. Cancer Res. 2000, 6, 693-700.

107. Clark, E.A.; Giltiay, N.V. CD22: A Regulator of Innate and Adaptive B Cell Responses and Autoimmunity. Front. Immunol. 2018, 9, 2235. [CrossRef]

108. Enterina, J.R.; Jung, J.; Macauley, M.S. Coordinated roles for glycans in regulating the inhibitory function of CD22 on B cells. Biomed. J. 2019, 42, 218-232. [CrossRef]

109. Kreitman, R.J.; Margulies, I.; Stetler-Stevenson, M.; Wang, Q.C.; FitzGerald, D.J.P.; Pastan, I. Cytotoxic activity of disulfide-stabilized recombinant immunotoxin RFB4(dsFv)-PE38 (BL22) towards fresh malignant cells from patients with B-cell leukemias. Clin. Cancer Res. 2000, 6, 1476-1487.

110. Alderson, R.F.; Kreitman, R.J.; Chen, T.; Yeung, P.; Herbst, R.; Fox, J.A.; Pastan, I. CAT-8015: A second-generation pseudomonas exotoxin A-based immunotherapy targeting CD22-expressing hematologic malignancies. Clin. Cancer Res. 2009, 15, 832-839. [CrossRef]

111. Kreitman, R.J.; Wang, Q.C.; FitzGerald, D.J.P.; Pastan, I. Complete regression of human B-cell lymphoma xenografts in mice treated with recombinant anti-CD22 immunotoxin RFB4(dsFv)-PE38 at doses tolerated by Cynomolgus monkeys. Int. J. Cancer 1999, 81, 148-155. [CrossRef]

112. Kreitman, R.J.; Hansen, H.J.; Jones, A.L.; FitzGerald, D.J.P.; Goldenberg, D.M.; Pastan, I. Pseudomonas exotoxin-based immunotoxins containing the antibody LL2 or LL2-Fab' induce regression of subcutaneous human B-cell lymphoma in mice. Cancer Res. 1993, 53, 819-825. [PubMed]

113. Theuer, C.P.; Kreitman, R.J.; FitzGerald, D.J.; Pastan, I. Immunotoxins made with a recombinant form of Pseudomonas exotoxin A that do not require proteolysis for activity. Cancer Res. 1993, 53, 340-347. [PubMed]

114. Mansfield, E.; Chiron, M.F.; Amlot, P.; Pastan, I.; FitzGerald, D.J. Recombinant RFB4 single-chain immunotoxin that is cytotoxic towards CD22-positive cells. Biochem. Soc. Trans. 1997, 25, 709-714. [CrossRef]

115. Moake, J.L. Thrombotic thrombocytopenic purpura and the hemolytic uremic syndrome. Arch Pathol. Lab. Med. 2002, 126, 1430-1433.

116. Salvatore, G.; Beers, R.; Margulies, I.; Kreitman, R.J.; Pastan, I. Improved Cytotoxic activity towards cell lines and fresh leukemia cells of a mutant anti-CD22 immunotoxin obtained by antibody phage display. Clin. Cancer Res. 2002, 8, 995-1002.

117. Kuan, C.; Pai, L.H.; Pastan, I. Immunotoxins containing Pseudomonas exotoxin targeting Le $\mathrm{L}^{\mathrm{Y}}$ damage human endothelial cells in an antibody-specific mode: Relevance to vascular leak syndrome. Clin. Cancer Res. 1995, 1, 1589-1594.

118. Lindstrom, A.L.; Erlandsen, S.L.; Kersey, J.H.; Pennell, C.A. An in vitro model for toxin-mediated vascular leak syndrome: Ricin toxin A chain increases the permeability of human endothelial cell monolayers. Blood 1997, 90, 2323-2334. [CrossRef]

119. Vitetta, E.S. Immunotoxins and vascular leak syndrome. Cancer J. 2000, 6, S218-S224.

120. Hassan, R.; Bullock, S.; Premkumar, A.; Kreitman, R.J.; Kindler, H.; Willingham, M.; Pastan, I. Phase I study of SS1P, a recombinant anti-mesothelin immunotoxin given as a bolus I.V. infusion to patients with mesothelin-expressing mesothelioma, ovarian, and pancreatic cancers. Clin. Cancer Res. 2007, 13, 5144-5149. [CrossRef]

121. Kreitman, R.J.; Hassan, R.; FitzGerald, D.J.; Pastan, I. Phase I Trial of Continuous Infusion Anti-Mesothelin Recombinant Immunotoxin SS1P. Clin. Cancer Res. 2009, 15, 5274-5279. [CrossRef] [PubMed]

122. Pai, L.H.; Wittes, R.; Setser, A.; Willingham, M.C.; Pastan, I. Treatment of advanced solid tumors with immunotoxin LMB-1: An antibody linked to Pseudomonas exotoxin. Nat. Med. 1996, 2, 350-353. [CrossRef] [PubMed]

123. Kreitman, R.J.; Stetler-Stevenson, M.; Jaffe, E.S.; Conlon, K.C.; Steinberg, S.M.; Wilson, W.; Waldmann, T.A.; Pastan, I. Complete Remissions of Adult T-cell Leukemia with Anti-CD25 Recombinant Immunotoxin LMB-2 and Chemotherapy to Block Immunogenicity. Clin. Cancer Res. 2016, 22, 310-318. [CrossRef] [PubMed]

124. Sausville, E.A.; Headlee, D.; Stetler-Stevenson, M.; Jaffe, E.S.; Solomon, D.; Figg, W.D.; Herdt, J.; Kopp, W.C.; Rager, H.; Steinberg, S.M.; et al. Continuous infusion of the anti-CD22 immunotoxin IgG-RFB4-SMPT-dgA in patients with B-cell lymphoma: A phase I study. Blood 1995, 85, 3457-3465. [CrossRef] [PubMed] 
125. Wayne, A.; Bhojwani, D.; Richards, K.; Stetler-Stevenson, M.; Silverman, L.B.; Jehac, S.; Pui, C.; McDevitt, J.; FitzGerald, D.J.; Kreitman, R.J.; et al. Complete Remissions In 3 of 12 Patients with Pediatric Acute Lymphoblastic Leukemia (ALL) During Phase I Testing of the Anti-CD22 Immunotoxin Moxetumomab Pasudotox. Am. Soc. Hematol. 2010. [CrossRef]

126. Wayne, A.S.; Shah, N.N.; Bhojwani, D.; Silverman, L.B.; Whitlock, J.A.; Stetler-Stevenson, M.; Sun, W.; Liang, M.; Yang, J.; Chang, L.; et al. Phase 1 study of the anti-CD22 immunotoxin moxetumomab pasudotox for childhood acute lymphoblastic leukemia. Blood 2017, 130, 1620-1627. [CrossRef]

127. Feurtado, J.; Kreitman, R.J. Moxetumomab Pasudotox: Clinical Experience in Relapsed/Refractory Hairy Cell Leukemia. Clin. J. Oncol. Nurs. 2019, 23, E52-E59. [CrossRef]

128. Vainshtein, I.; Sun, B.; Roskos, L.K.; Liang, M. A novel approach to assess domain specificity of anti-drug antibodies to moxetumomab pasudotox, an immunotoxin with two functional domains. J. Immunol. Methods 2020, 477, 112688. [CrossRef]

129. Kuruvilla, D.; Chia, Y.L.; Balic, K.; Yao, N.S.; Kreitman, R.J.; Pastan, I.; Li, X.; Standifer, N.; Liang, M.; Tseng, C.; et al. Population Pharmacokinetics, Efficacy, and Safety of Moxetumomab Pasudotox in Patients With Relapsed or Refractory Hairy Cell Leukemia. Br. J. Clin. Pharmacol. 2020, 86, 1367-1376. [CrossRef]

130. Hassan, R.; Williams-Gould, J.; Watson, T.; Pai-Scherf, L.; Pastan, I. Pretreatment with Rituximab Does Not Inhibit the Human Immune Response against the Immunogenic Protein LMB-1. Clin. Cancer Res. 2004, 10, 16-18. [CrossRef]

131. Nieva, J.; Bethel, K.; Saven, A. Phase 2 study of rituximab in the treatment of cladribine-failed patients with hairy cell leukemia. Blood 2003, 102, 810-813. [CrossRef] [PubMed]

132. Tiacci, E.; Carolis, L.D.; Simonetti, E.; Zaja, F.; Capponi, M.; Ambrosetti, A.; Lucia, E.; Antolino, A.; Pulsoni, A.; Ferrari, S.; et al. The BRAF inhibitor vemurafenib plus rituximab produces a high rate of deep and durable responses in relapsed/refractory hairy cell leukemia: Updated results of a phase-2 trial. Hematol. Oncol. 2019, 37, 110-111. [CrossRef]

(C) 2020 by the authors. Licensee MDPI, Basel, Switzerland. This article is an open access article distributed under the terms and conditions of the Creative Commons Attribution (CC BY) license (http://creativecommons.org/licenses/by/4.0/). 